\title{
GAGASAN PEMBAHARUAN PENDIDIKAN ISLAM MUHAMMAD ABDUH (1849-1905)
}

\author{
Cahaya Khaeroni \\ Mahasiswa Doktoral UIN Syarif Hidayatullah Jakarta \\ Email: c.khaeroni@gmail.com
}

\begin{abstract}
This paper analyzes the contributions of Shaykh Muhammad 'Abduh to modernity, and his struggle for change and reform in Egyptian society. Abduh was hailed as the "first leader of modern thought in Egypt", "the father of the 20th century Muslim thought" and "pioneers of the modernist movement in the Arab world", whose legacy in the history of Islamic reform was significant, carrying dynamic role in the transformation and reinterpretation of Islam in contemporary thought. His contribution to Islamic modernism was clearly seen in liberalizing the educational system, transforming the Islamic worldview, and integrating western and Islamic ideals and tradition.
\end{abstract}

Keywords: Muhammad Abduh, Islamic modernism, educational reform.

\section{PENDAHULUAN}

Gerakan pembaharuan Islam di Mesir muncul sekitar abad ke-19 M, gerakan ini berawal dari kesadaran umat Muslim yang secara faktual ternyata benar-benar sudah jauh tertinggal dari bangsa-bangsa Eropa. Beberapa tokoh pembaharu telah lahir akibat kondisi ketertinggalan bangsa Mesir tersebut, diantaranya adalah Muhammad Abduh yang dikenal sebagai seorang pembangun dimensi pembaharu sosial dan intelektualis dalam modernisme Islam.

Dalam pandangannya, Abduh bahwa kemunduran masyarakat Muslim sesungguhnya disebabkan oleh faham jumud yang terdapat dikalangan umat Islam. Dalam kata jumud, terkandung arti keadaan membeku, keadaan statis, dan tak ada perubahan. Karena dipengaruhi faham jumud, umat Islam tidak menghendaki perubahan dan tidak mau menerima perubahan. Hal ini ditambah dengan adanya taqlid yang sudah mengakar dalam jiwa kaum muslimin pada waktu itu sehingga melemahkan jiwa mereka, untuk itulah, Abduh meniscayakan perlu adanya pembaharuan dalam tubuh umat Muslim.

Berbeda dengan pendahulunya, seperti Jamaluddin al-Afghani yang cenderung melakukan gagasan pembaharuannya lewat politik sebagaimana tertuang dalam ide populernya tentang Pan-Islamisme (gagasan mengenai persatuan seluruh umat Islam). Muhammad Abduh justru memalingkan diri dari aktifitas politik dan lebih memusatkan perhatiannya pada pembaharuan pemikiran agama, sosial dan pendidikan. 
Dalam lingkup pemikiran agama, Abduh memberikan alasan mengenai perlunya pembaruan hukum Islam. Dia mengemukakan bahwa kalau hukum yang menyangkut peribadatan kepada Tuhan tak dapat berubah, sedangkan hukum sosial Islam dapat mengalami perubahan substantif. Seperti yang tertulis dalam karyanya harian al-Manar (mercusuar) yang berisi penafsiran ayat alQur'an dan ilmu ketuhanan. Dia mengajarkan kecocokan wahyu Tuhan dengan nalar, mengutuk sikap yang mengikuti hadits Nabi secara membabi buta, mengunggulkan legitimasi dan perlunya penafsiran kembali Islam sebagai tanggapan terhadap tuntutan zaman modern. Muhammad Abduh juga merupakan tokoh yang memperbaiki status wanita dalam Islam. Dia juga mengecam poligami dan dampak negatifnya terhadap keluarga Islam. Dia mengungkapkan bahwa hal itu pernah diperbolehkan sehubungan dengan keadaan sosial yang dialami di Arab pada zaman Nabi Muhammad. Abduh memberi penafsiran bahwa ideal al-Qur'an adalah monogami, karena izin yang diberikan oleh alQur'an untuk lebih dari satu itu dibarengi dengan syarat agar berlaku adil dan tidak berat sebelah, yang keduanya tidak mungkin dapat dilakukan. ${ }^{1}$

Sementara itu, dalam lingkup pendidikan juga merupakan salah satu hal terpenting yang menjadi perhatian Abduh sepanjang hayat dan karirnya. bekerja untuk memperbaharui para ulama, khususnya kurikulum di Universitas al-Azhar, dan pengadilan agama.

Kajian yang dilakukan dalam tulisan ini memiliki dua tujuan, diantaranya: Pertama, mengeksplorasi gagasan-gagasan pembaharuan Muhammad Abduh dalam konteks keislaman. Kedua, mengeksplorasi dan mengalisis secara lebih lanjut gagasan pembaharuan Muhammad Abduh dalam konteks pendidikan Islam. Adapun ditinjau dari segi manfaat, kajian dalam tulisan ini dapat memberikan dua manfaat, diantaranya: pertama, secara teoritisakademis, kajian ini diharapkan dapat menambah khazanah keilmuwan dalam kerangka berfikir pembaharuan Islam khususnya dalam bidang pendidikan. Kedua, Secara praktis-empiris, kajian ini diharapkan dapat menjadi masukan kepada setiap peminat kajian-kajian pembaharuan Keislaman maupun pendidikan Islam, sehingga dapat memiliki peta kajian yang komprehensif dalam mewacanakan pembaharuan dalam konteks keislaman.

Dalam tulisan ringkas ini, penulis hendak mencoba menguraikan lebih mendalam gagasan-gagasan Muhammad Abduh mengenai pembaharuan Islam dan secara spesifik gagasan pembaharuan dalam pendidikan Islam, dengan harapan semoga tulisan ini dapat memberikan kontribusi signifikan dalam memajukan khazanah keilmuan dan keIslaman di Negeri Indonesia tercinta, amin.

\footnotetext{
${ }^{1}$ John L. Esposito, Ancaman Islam; Mitos atau Realitas?, Bandung: Mizan, 1996, h. 69-70. 60 
Adapaun permsalahan dalam tulisan ini adalah untuk mengetahui:

1. Bagaimana gagasan-gagasan pembaharuan Muhammad Abduh dalam konteks keIslaman?

2. Bagaimana gagasan-gagasan pembaharuan Muhammad Abduh dalam ranah pendidikan Islam?

\section{KAJIAN TEORI \\ Gagasan Pembaharuan}

pembaharuan di sebuah tempat akan selalu beriringan dengan kemajuan ilmu pengetahuan dan teknologi yang berkembang saat itu. Modernisasi atau pembaharuan bisa diartikan apa saja yang belum di pahami, di terima, atau dilaksanakan oleh penerima pembaharuan sesungguhnya lebih merupakan upaya atau usaha perbaikan keadaan baik dari segi cara, konsep, dan serangkaian metode yang biasa diterapkan dalam rangka menghantarkan keadaan yang lebih baik $^{2}$

Pembaharuan identik dengan kata modern, modernisasi, dan modernisme, seperti yang terdapat umpanya dalam aliran-aliran modern dalam islam dan modernisasi. Modern dalam masyarakat barat mengandung arti fikiran, gerakan dan usaha untuk merubah faham-faham, adat-istiadat, instilusi-inslutusi lama dan sebagainya untuk disesuaikan dengan suasana baru yang ditimbulkan oleh kamajuan ilmu pengetahuan dan teknologi modern ${ }^{3}$

Dengan demikian, Apabila dikaitkan dengan gagasan pembaharuan pendidikan Islam akan memberi pengertian bahwa suatu upaya melakukan proses perubahan kurikulum, cara, metodologi, situasi dan pendidikan Islam dari yang tradisional (ortodox) kearah yang lebih rasional, dan professional sejalan dengan perkembangan ilmu pengetahuan dan teknologi pada waktu itu.

\section{Sekilas Riwayat Kehidupan Muhammad Abduh}

Muhammad Abduh dilahirkan pada tahun 1849 M (1265 H) di Mahallah Nasr, suatu perkampungan agraris ternasuk Mesir Hilir di propinsi Gharbiyyah. Ayahnya bernama Abduh bin Hasan Chairullah, seorang berdarah Turki, sedangkan ibunya Junainah binti Utsman al-Kabir mempunyai silsilah keluarga besar keturunan Umar bin Khattab. Kedua orang tua Abduh hidup dalam masa rezim Muhammad Ali Pasya, yang memerintah Mesir dengan segala kelebihan dan kekurangannya. Karena ketidakcocokan dengan beberapa kebijakan penguasa, ayah Abduh pernah dituduh hendak menentang pemerintah yang kemudian menyebabkannya masuk tahanan. Situasi sosial-politik yang demikian mengakibatkan kedua orang tua Abduh tidak sempat memperoleh pendidikan

\footnotetext{
${ }^{2}$ Harun Nasution, Upaya Pembaharuan dalam Pendidikan dan Pengajaran, Bandung: PT. Remaja Rosdakarya,1992, h.6

${ }^{3}$ Harun Nasution, Pembahasan dalam Islam Sejarah Pemikiran dan Gerakan, Jakarta : Bulan Bintang, 1992, h.11
} 
yang tinggi. Meskipun demikian, keluarga Abduh Chairullah dikenal sangat kuat dalam menjalankan agama, dan inilah yang dijadikan pijakan dalam membesarkan anak-anaknya. ${ }^{4}$

Sampai usia 10 tahun Abduh dididik dalam lingkungan keluarga sendiri terutama mengenai membaca dan menulis. Setelah itu sang ayah mengirimnya kepada seorang hafidz untuk belajar al-Qur'an dan hanya dalam tempo dua tahun ia sudah berhasil menghafalkannya. Studinya tentang al-Qur'an ini kemudian dimantapkannya di Masjid Syekh Ahmad, di kota Thanta yang terkenal mempunyai spesialisasi dalam kajian Qur'an. Di sini pulalah Abduh mempelajari ilmu-ilmu tradisional keislaman seperti ilmu tata bahasa dan fiqih. Namun, Abduh sendiri merasa tak mengerti apa-apa. Tentang pengalaman ini Abduh pernah mengatakan: "Satu setengah tahun saya belajar di Mesjid Syekh Ahmad dengan tak mengerti apapun. Ini adalah karena metodenya yang salah, guru-guru mulai mengajak kita dengan menghafal istilah-istilah tentang nahwu atau fiqh yang tak kita mengerti atau tidak mengerti arti-arti istilah itu. Hal ini disebabkan metode yang dipakai pada waktu itu ialah metode menghafal diluar kepala. Karena tidak puas dengan metode menghafal diluar kepala ini, Muhammad Abduh akhirnya lari dan meninggalkan pelajarannya di Tantha. ${ }^{5}$

Sewaktu baru berumur 16 tahun, Abduh-pun menikah. Namun, baru saja empat puluh hari menikah, ia dipaksa orang tuanya untuk kembali belajar ke Tantha. Ia pun meninggalkan kampungnya, tetapi bukannya pergi ke Tantha, Abduh malahan bersembunyi lagi dirumah pamannya. Dan disini, Abduh bertemu dengan seseorang yang merubah riwayat hidupnya. Orang tersebut bernama syeikh Darwisy Khadr yang sekaligus adalah paman dari ayahnya sendiri. Pada mulanya Syekh Darwisy tahu bahwa Abduh cukup enggan untuk belajar, maka ia selalu membujuk pemuda tersebut untuk ikut membaca bersama-sama dengannya. Kengganan Abduh dalam belajar rupanya selalu dibarengi dengan bimbingan yang penuh kesabaran dari Syekh Darwisyi tersebut, hal ini sebagaimana yang diceritakan oleh Muhammad Abduh sendiri, ia pada waktu itu sangat benci melihat buku, dan buku yang diberikan Syekh Darwisy kepadanya untuk dibaca ia lemparkan jauh-jauh. Buku itu dipungut Syekh Darwisy kembali dan diberikan kepadanya dan akhirnya Abduh membaca juga beberapa baris. Setiap habis satu kalimat,

Syekh Darwisy memberikan penjelasan luas tentang arti dan maksud yang dikandung kalimat itu. Setelah beberapa hari membaca buku bersama-sama dengan cara yang diberikan Syekh Darwisy itu, Muhammad Abduh pun berubah secara drastis sikapnya terhadap buku dan ilmu pengetahuan. Ia sekarang mulai

\footnotetext{
${ }^{4}$ Ahmad Amir, Pembaruan Teologi; Perspektif Modernisme Muhammad Abduh dan Neo Modernisme Fazlur Rahman, (Yogyakarta: Teras, 2009), h. 10.

${ }^{5}$ Harun Nasution, Pembaharuan dalam Islam; Sejarah Pemikiran dan Gerakan, Jakarta: Bulan Bintang, 1996, h. 59.
} 
mengerti dan mengetahui lebih banyak. ${ }^{6}$ Setelah belajar di Thanta, pada tahun 1866 ia meneruskan ke perguruan tinggi al-Azhar di Cairo, dan di sinilah ia bertemu dan berkenalan dengan Sayyid Jamaluddin al-Afghani.

Ketika Jamaluddin Al-Afghani datang ke Mesir pada tahun 1871 M, dan sekaligus untuk menetap di Mesir, Muhammad Abduh pun langsung menjadi muridnya yang paling setia. Ia belajar filsafat di bawah bimbingan Afghani dan di masa inilah ia mulai membuat karangan harian al-Ahram yang pada saat itu baru didirikan. Pada tahun 1877 studinya di al-Azhar selesai dengan hasil yang sangat baik dan ia mendapatkan gelar alim. Kemudian ia diangkat menjadi dosen al-Azhar disamping itu ia mengajar di Universitas Darul Ulum. Karena hubungannya dengan Jamaluddin al-Afghani dituduh mengadakan gerakan menentang Khadewi Taufik, maka Muhammad Abduh yang juga turut dipandang turut campur dalam persoalan ini dibuang keluar kota Cairo, tetapi setahun kemudian, di tahun $1880 \mathrm{M}$, dia dibolehkan kembali ke ibukota dan kemudian diangkat menjadi redaktur surat kabar resmi pemerintah Mesir yang bernama $\mathrm{Al}$ Waqa'il Mishriyah, yang dibantu oleh Sa'ad Zaglul Pasya, yang kemudian ternyata menjadi pemimpin Mesir yang termasyhur. Dengan majalah ini Muhammad Abduh mendapat kesempatan yang lebih luas menyampaikan ideidenya, melalui artikel-artikelnya yang hangat dan tinggi nilainya tentang ilmu agama, filsafat, kesusasteraan, dan lain-lain. Ia juga mempunyai kesempatan untuk mengadakan kritikan terhadap pemerintah tentang nasib rakyat, pendidikan dan pengajaran di Mesir. ${ }^{7}$

Dalam peristiwa pemberontakan Urabi Pasya (1882), Muhammad Abduh ikut terlibat didalamnya, sehingga ketika pemberontakan itu berakhir, ia diusir dari Mesir. Dalam pembuangannya ia memilih Syiria (Beirut), disini ia mendapat kesempatan mengajar pada perguruan tinggi Sultaniah, kurang lebih satu tahun lamanya. Kemudian ia pergi ke Paris atas panggilan Sayid Jamaluddin alAfghani, yang pada waktu itu tahun 1884 telah berada di sana. Bersama-sama Jamaluddin al-Afghani disusunlah suatu gerakan yang bernama "Al-Urwatul Wusqa" suatu gerakan kesadaran umat Islam sedunia. ${ }^{8}$ Tujuan gerakan/organisasi ini adalah untuk menyatukan umat Islam, dan sekaligus melepaskan dari sebab-sebab perpecahan mereka. Setelah 18 bulan di Paris organisasi tersebut bubar dan Abduh kembali mengajar di Beirut. Di situlah ia menulis Risalatut Tauhid' dan menterjemahkan Al-Rad 'Alaal Dahriyin, buku

\footnotetext{
${ }^{6}$ Ibid, h. 60.

${ }^{7}$ Yusran Asmuni, Pengantar Studi Pemikiran dan Gerakan Pembaharuan dalam Dunia Islam, (Jakarta: PT Raja Grafindo Persada, 1998), h. 79.

${ }^{8}$ Ibid, h. 80.

${ }^{9}$ Risalat al-Tauhid, merupakan karyanya yang sistematis yang diambil dari kuliah-kuliahnya tentang teologi di Beirut. Risalat al-Tauhid menggambarkan suatu mata rantai panjang risalah-risalah skolastik yang telah diprakarsai oleh doktor-doktor Mu'tazilah pada abad ke-delapan. Risalah ini dimulai dengan uraian tentang definisi teologi atau "ilmu tauhid" seperti studi tentang eksistensi Tuhan, keesaanNya, sifat-sifat-Nya, dan sifat wahyu kenabian. Menurut pengamatannya, sebelum munculnya Islam teologi belum dikenal, tetapi metode demonstrasi yang digunakan oleh para teolog pra-Islam cenderung menjadi
} 
tulisan Jamaluddin al-Afghani yang semula berbahasa Perancis. Di sini pula ia menikah untuk kedua kalinya setelah istrinya yang pertama meninggal. ${ }^{10}$

Setelah diijinkan untuk kembali ke Mesir, pada tanggal 3 Juni 1899 beliau diserahi oleh pemerintah untuk memangku jabatan "Mufti Mesir", yaitu suatu jabatan yang paling tinggi menurut pandangan kaum Muslimin. Berbeda dengan mufti-mufti sebelumnya, Abduh tidak mau membatasi dirinya hanya sebagai alat penjawab pertanyaan-pertanyaan pemerintah saja, tetapi ia memperluas tugas jabatan itu untuk kepentingan kaum Muslimin. Apa saja masalah-masalah yang timbul di kalangan kaum Muslimin, terutama bangsa Mesir, yang dihadapkan kepadanya, dilayaninya dengan senang hati dan diselesaikannya dengan baik. ${ }^{11}$ Jabatan tersebut dipegangnya hingga ia meninggal dunia pada tanggal 11 Juli 1905.

Di samping itu pula, ia juga diangkat menjadi anggota Majelis Perwakilan (Legislative Council), Muhammad Abduh pernah juga diserahi jabatan Hakim Mahkamah, dan di dalam tugas ini ia dikenal sebagai seorang hakim yang adil. ${ }^{12}$

\section{PEMBAHASAN}

\section{Pemikiran dan Ide Pembaharuan Muhammad Abduh}

Dipandang dalam aspek pembaruan teologi dan hukum, maka Muhammad Abduh dapat digolongkan sebagai seorang pembaharu pada zamannya. Pemikirannya muncul atas situasi dan tuntutan sosial yang mengharuskannya melakukan pembaharuan. Oleh sebab itulah ia digolongkan sebagai kaum modernis, yakni orang yang paling cepat tanggap merespon perkembangan yang terjadi dan sekaligus paling cepat diresponi oleh masyarakat sekitarnya.

Kalau dicermati secara seksama, sesungguhnya gagasan pembaruan Abduh bertumpu pada tiga hal berikut; (1) Pembebasan pemikiran dari belenggu taqlid sehingga akal tidak tunduk pada otoritas manapun. (2) Purifikasi (Gerakan Pemurnian ajaran Islam). (3) Penempatan agama sejajar dengan perkembangan ilmu pengetahuan, atau dengan kata lain, menjadikan sains sebagai partner

\footnotetext{
suatu jenis adikodrati atau preternatural, seperti himbauannya kepada mukjizat (keajaiban-keajaiban), pembicaraan retorik, atau legenda. Al-Qur'an menentang semua itu. Ia menyingkapkan dengan suatu cara yang tidak dapat ditiru "pengetahuan apa yang tidak dapat dibolehkan atau ditentukan Tuhan, tetapi tidak menentukan penerimaannya semata-mata atas dasar wahyu. Tetapi dengan mengajarkan pembuktian dan demonstrasi, menguraikan pandangan-pandangan orang yang tidak beriman, dan membantah mereka secara rasional. Ringkasnya ia menyatakan akal sebagai penentu terakhir tentang kebenaran dan menetapkan perintah-perintah moralnya atas dasar-dasar rasional yang kokoh. Lihat: Majid Fakhry, Sejarah Filsafat Islam, terj. Mulyadhi Kartanegara, (Jakarta: Pustaka Jaya, 1987, h. 464-465.

${ }^{10}$ Mukti Sahal dan Ahmad Amir Azizi, Teologi Islam Modern, Surabaya: Gitamedia Press, 1992, h. 17.

${ }^{11}$ Kata pengantar dalam: Muhammad Abduh, Risalah Tauhid, terj. Firdaus, (Jakarta: Bulan Bintang, 1996, h. xi.

${ }^{12}$ Yusran Asmuni, Pengantar Studi Pemikiran ....,Jakarta: PT Raja Grafindo Persada, 1998, h. 80. 64
} 
agama. Berikut akan diuraikan secara lebih mendalam pokok-pokok pemikiran Muhammad Abduh tersebut.

Muhammad Abduh berhasil menulis sekian banyak karya ilmiah, antara lain adalah:

1. Al-Hikmah asy-Syar'iyah fi Muhakamat Al-Dadiriyah wa AlRifa'iyah. Buku ini adalah karya pertamanya diwaktu ia masih belajar, isinya adalah bantahan kepada Abdul Hadyi Ash-Shayyad yang mengecilkan tokoh sufi besar Abdulkadir Al-Jailani, juga menjelaskan kekeliruan-kekeliruan yang dilakukan oleh para penganut tasawuf, tentang busana Muslim, sikap meniru non-Muslim, Imam Mahdi, masalah dakwah dan kekeramatan.

2. Al-Azhar dan Al-Manar. Isinya, antara lain, sejarah Al-Azhar, perkembangan dan misinya, serta bantahan terhadap sementara ulama Azhar yang menentang pendapat-pendapatnya.

3. Tarikh Al-Ustadz Al-Imam, berisi riwayat Muhammad Abduh dan perkembangan masyarakat Mesir pada masanya.

4. Nida'li Al-Jins Al-Lathif, berisi uraian tentang hak dan kewajibankewajiban wanita.

5. Zikra Al-Maulid An-Nabawi.

6. Risalatu Hujjah Al-Islam Al-Ghazali.

7. Al-Sunnah wa Al-Syi'ah.

8. Al-Wahdah Al-Islamiyah.

9. Haqiqah Al-Riba.

10. Majalah Al-Manar, yang terbit sejak $1315 \mathrm{H} / 1898$ M sampai dengan $1354 \mathrm{H} / 1935 \mathrm{M}$.

11. Tafsir Al-Manar.

12. Tafsir surah-surah Al-Kautsar, Al-Kafirun, Al-Ikhlas, dan AlMu'awidzatayn. ${ }^{13}$

13. Risalah al-Tauhid, yang merupakan karya paling monumental dari Muhammad Abduh. ${ }^{14}$

\section{Pembebasan pemikiran dari belenggu taqlid}

Dalam masalah ini Abduh tidak menghendaki adanya taqlid, dan mengobarkan seruan agar pintu ijtihad selalu terbuka. Bahkan dengan bersemangat ia menyampaikan bahwa tidak ada pertentangan antara ilmu dan agama, ${ }^{15}$ al-Qur'an bukan saja sesuai dengan ilmu pengetahuan tapi juga mendorong semangat umat Islam untuk mengembangkannya. ${ }^{16}$

${ }^{13}$ M. Quraish Shihab, Studi Kritis Tafsir Al-Manar; Karya Muhammad Abduh dan M. Rasyid Ridha, Bandung: Pustaka Hidayah, 1994, h. 65-66.

${ }^{14}$ Ahmad Amir Aziz, Pembaruan Teologi..., Yogyakarta: Teras, 2009, h. 15.

${ }^{15}$ Hal ini sebagaimana yang diungkapkan oleh Muhammad Abduh sendiri dalam tulisannya yang berjudul Islam, Penalaran dan Peradaban: "Dalam segala hal, agama jangan dianggap sebagai penghalang, yang memisahkan semangat manusiawi dengan kemampuan-kemampuan yang diberikan Allah untuk 65 
Ide Muhammad Abduh tersebut ternyata mendapatkan sambutan yang cukup luas dan hampir menyebar ke seluruh dunia Islam. seruannya untuk anti taqlid, memang mencerminkan kenyataan umat Islam yang tengah mengalami kejumudan berpikir. Sikap demikian pada gilirannya mengalami sikap antipati terhadap sains modern, dan merupakan sikap yang harus dihapuskan menurut Abduh.

Dalam beberapa hal, pemikiran Abduh memiliki garis penghubung dengan Muhammad bin Abdul Wahab, yakni ingin mengembalikan pemahaman agama sebagai ulama salaf. Kendatipun demikian, karena sikapnya yang sangat positif terhadap sains, Abduh berpendapat bahwa ajaran-ajaran Islam perlu diberi interpretasi baru, dan pintu ijtihad harus dibuka selebar-lebarnya. Ijtihad menurut pendapatnya bukan hanya boleh, malahan penting dan perlu diadakan. Tetapi yang dimaksudkannya bukan tiap-tiap orang boleh melakukan ijtihad. Hanya orang yang memenuhi syarat-syarat yang diperlukan yang boleh melakukan ijtihad. Yang tak memenuhi syarat, harus mengikuti pendapat mujtahid yang ia setujui fahamnya. Ijtihad dilakukan langsung pada al-Qur'an dan Hadis sebagai sumber yang asli dari ajaran-ajaran Islam.

Dengan demikian, taqlid kepada ulama lama tak perlu dipertahankan bahkan mesti diperangi karena taqlid inilah yang membuat umat Islam berada dalam kemunduran dan tak dapat maju. Pendapat tentang pemberantasan taqlid dan pembukaan pintu ijtihad didasarkan atau kepercayaannya pada kekuatan akal. Menurut abduh, al-Qur'an berbicara bukan semata kepada hati manusia, tetapi juga kepada akalnya.

Kepercayaan pada kekuatan akal membawa Muhammad Abduh selanjutnya kepada faham bahwa manusia mempunyai kebebasan dalam kemauan dan perbuatan (free will and free act atau qadariyah), dengan faham tersebut, maka manusia akan bebas mewujudkan perbuatannya dengan kemauan dan usahanya sendiri, dan tentunya dengan tidak melupakan bahwa diatasnya masih ada kekuasaan yang lebih tinggi.

\section{Purifikasi (Gerakan pemurnian ajaran Islam)}

Abduh berupaya untuk memurnikan ajaran Islam dengan kembali pada alQur'an dan Hadis Nabi, hal ini terkait dengan banyaknya fenomena bid'ah dan

mengetahui kebenaran di dunia ini sepanjang ia berada di dalamnya. Tepatnya, agama harus meningkatkan penelitian terhadap kebenaran ini, menuntut perhatian untuk mencari bukti dan memerintahkan untuk mencapai tingkat pengabdian dan usaha yang benar-benar dalam lapangan ilmu pengetahuan itu-juga segala sesuatu yang ada dalam proporsi-proporsi tujuan yang benar, dengan memperhitungkan waktunya secara tepat. Barang siapa tidak mengimani tidak akan tahu apakah sebenarnya agama itu dan bahkan merendahkannya, sesuatu yang tidak akan diampuni oleh Tuhan seru sekalian alam”. Lihat: John J. Donohue dan John L. Esposito (ed), Islam dan Pembaharuan; Ensiklopedi masalah-masalah, terj. Machnun Husein, Jakarta: Rajawali, 1984, h. 30-31.

${ }^{16}$ Yusran Asmuni, Pengantar Studi Pemikiran....Jakarta: PT Raja Grafindo Persada, 1998, h. 81. 
khurafat. Menurutnya, kaum Muslim tidak perlu mempercayai adanya karamah yang dimiliki wali atau kemampuan mereka sebagai perantara atau wasilah kepada Allah. Syirik harus dihindari karena tidak sesuai dengan akidah Islam. ${ }^{17}$

Lebih lanjut, Abduh juga menekankan bahwa mentauhidkan Allah merupakan pangkal dari segala keimanan yang lainnya. Dalam hal ini seruan mentauhidkan itu tidak bersandar pada dalil apapun kecuali nash qath'iy yang dipadukan dengan pemakaian rasio yang benar. Inilah salah satu prinsip penting yang menjadi pedoman Abduh. Abduh telah mencoba menempatkan posisi tauhid pada posisinya yang lurus dengan mengesampingkan bentuk-bentuk pemahaman keagamaan yang mempunyai kekuatan sumber (otoritas). ${ }^{18}$

Dalam pandangan Abduh, bahwa masuknya berbagai macam bid'ah ke dalam Islamlah yang membuat Islam lupa akan ajaran-ajaran Islam yang sebenarnya. Bid'ah-bid'ah itulah yang mewujudkan masyarakat Islam yang jauh menyeleweng dari masyarakat Islam yang sebenarnya. Untuk menolong umat Islam, faham-faham asing lagi salah itu harus dikeluarkan dari tubuh Islam. Umat harus kembali ke ajaran-ajaran Islam yang semula, ajaran-ajaran sebagaimana terdapat di zaman salaf, yaitu di zaman sahabat dan ulama-ulama' besar. ${ }^{19}$

Perlu ditegaskan juga bahwa bagi Muhammad Abduh tidak cukup hanya kembali kepada ajaran-ajaran asli itu, karena zaman dan suasana umat Islam sekarang telah jauh berubah dari zaman dan suasana umat Islam zaman klasik, ajaran-ajaran asli itu perlu disesuaikan dengan keadaan modern sekarang.

\section{Pembaharuan dalam pendidikan Islam}

Program pembaharuan Abduh juga berfokus pada pembaharuan pendidikan Islam dan perumusan ajaran-ajaran Islam dalam pengertian, kalau tidak menurut pemikiran modern, setidak-tidaknya yang lebih bisa diterima oleh orang-orang modern. Tantangan pendidikan Islam terutama berkaitan dengan masalah orientasi pendidikan Islam, sumber daya manusia, anggaran pendidikan, kurikulum, informasi dan teknologi, globalisasi ${ }^{20}$

Dari pada perumusan abad pertengahan yang sudah ketinggalan zaman. Secara ideal kedua butir ini merupakan dua aspek dari kegiatan yang sama dan merupakan kelengkapan yang diperlukan untuk melaksanakan pemurnian Islam. Karena hanya dengan meningkatkan mutu pendidikan Islam dan mengemukakan kembali ajaran-ajaran dasar Islam dengan tegas dan jelas, pengaruh-pengaruh

${ }^{17}$ Erva Yuly Rakhmawanti, Muhammad Abduh dan Gagasan Pembaharuan Islam, Makalah tidak diterbitkan, h. 6 .

${ }^{18}$ Mukti Sahal dan Ahmad Amir Azizi, Teologi Islam..., (Surabaya: Gitamedia Press, 1992, h. 33.

${ }^{19}$ Harun Nasution, Pembaharuan dalam Islam... ,Jakarta: Bulan Bintang, 1996, h. 63.

${ }^{20}$ M. Ihsan Dacholfany, Reformasi Pendidikan Islam Dalam Menghadapi Era Globalisasi: Sebuah Tantangan dan Harapan, Akademika, STAIN Metro, Vol. 20, No. 01 Januari - Juni 2015, h.179 
yang merusak, baik yang bersifat animistik maupun materialistik dapat dikeluarkan dan dilenyapkan. ${ }^{21}$

Dalam pandangan Abduh, konsep pendidikan yang dikemukakan oleh Jamaluddin dalam bukunya "Refutation of the Materialistik" (Ar-Raddu' 'alad Dahriyyin) begitu umum pengertian-pengertiannya, sehingga sedikit saja menunjukkan pemikirannya. Dilain pihak, penolakan Abduh terhadap idealisme revolusioner Jamaluddin Al-Afghani menjadikan Abduh untuk lebih memfokuskan tujuan utamanya untuk mengembangkan landasan pendidikan, terutama universitas al-Azhar. ${ }^{22}$ Salah satu artikelnya yang dikirimkannya ke surat kabar Al-ahram pada tahun 1876, yang meskipun ketika itu dia masih dibawah pengaruh Jamaluddin al-Afghani, ia menyatakan dengan tegas bahwa kewajiban belajar tidak hanya mengenai buku-buku klasik berbahasa Arab dan tentang ilmu-ilmu kalam dogmatik dalam rangka membela agama, tetapi juga berbagai sains modern serta sejarah dan agama eropa agar dapat mengetahui sebab-sebab kemajuan bangsa-bangsa Barat. ${ }^{23}$

Penegasan Abduh untuk memasukkan materi sains modern kedalam kurikulum al-Azhar juga dilandaskan pada kegelisahannya terhadap munculnya dua tipe pendidikan di Mesir pada waktu itu. Tipe pertama, sekolah-sekolah tradisional dengan al-Azhar sebagai lembaga pendidikan tertinggi, tipe kedua, sekolah-sekolah modern baik yang didirikan oleh pemerintah Mesir maupun oleh para missionaris asing. Pada waktu itu, sekolah-sekolah agama semata-mata mengajarkan ilmu agama belaka, dan mengabaikan ilmu-ilmu umum atau tidak mengajarkan ilmu-ilmu yang datang dari Barat. Sementara sekolah-sekolah modern tampil dengan kurikulum yang memberikan ilmu pengetahuan Barat sepenuhnya, tanpa adanya upaya untuk memasukkan ilmu pengetahuan agama ke dalam kurikulumnya. ${ }^{24}$

Adanya dua tipe pendidikan tersebut juga berdampak pada munculnya dua kelas sosial dengan motivasi yang berbeda. Tipe sekolah pertama melahirkan para ulama dan tokoh masyarakat yang enggan menerima perubahan atau

21 Abduh memperjuangkan sistem pendidikan fungsional yang bukan impor, yang mencakup pendidikan universal bagi semua anak, laki-laki maupun perempuan. Semuanya harus punya kemampuan dasar seperti membaca, menulis dan berhitung. Semuanya harus mendapat pendidikan agama. Disamping itu, isi dan lama pendidikan haruslah beragam, sesuai dengan tujuan dan profesi yang dikehendaki oleh pelajar, dan semua kalangan behak untuk mendapatkan pendidikan, seperti anak petani, anak tukang, pedagang dan lain sebagainya. Lihat: Ali Rahnema (ed), Para Perintis Zaman Baru Islam, terj. Ilyas Hasan, Bandung: Mizan anggota IKAPI, 1996, h. 59.

${ }^{22}$ Penolakan Abduh terhadap gagasan idealisme revolusioner Jamaluddin al-Afghani didasarkan pada keyakinannya bahwa untuk membebaskan bangsa dari penjajahan dan kediktatoran diperlukan penguatan dalam bidang pendidikan dan pengajaran dan bukan semacam kudeta atau revolusi sebagaimana yang dilakukan oleh Jamaluddin al-Afghani. Lihat: Husayn ahmad amir, Seratus Tokoh dalam Sejarah Islam, terj. Bahruddin Fanani , Bandung: PT Remaja Rosdakarya, 1995, h. 303.

${ }^{23}$ H.A.R. Gibb, Aliran-aliran Modern dalam Islam, terj. Machnun Husein, Jakarta: PT Raja Grafindo Persada, 1993, h. 70

${ }^{24}$ Suwito dan Fauzan (ed), Sejarah Pemikiran Para Tokoh Pendidikan, Bandung: Angkasa, 2003, h. 307 . 
perkembangan dan cenderung mempertahankan tradisi. Sedang tipe sekolah kedua melahirkan kelas elit generasi muda yang mendewakan dan menerima perkembangan dari Barat tanpa melakukan filterisasi. Muhammad Abduh melihat bahwa terdapat segi-segi negatif dari kedua bentuk pemikiran itu, sehingga ia mengkritik kedua corak lembaga tersebut. Ia memandang bahwa jika pola fikir pertama tetap dipertahankan, maka akan membuat umat Islam tertinggal jauh dan semakin terdesak oleh arus kehidupan dan pola hidup modern. Sementara pola fikir kedua, penekanan pada pemikiran modern yang mereka serap dari Barat namun tanpa penanaman nilai-nilai religius, merupakan bahaya yang akan mengancam sendi-sendi agama dan moral. ${ }^{25}$ Untuk itulah, bagi Abduh dualisme yang terjadi dalam dua lembaga pendidikan tersebut harus dihapuskan. Terlebih pembenahan kepada lembaga-lembaga pendidikan agama semacam al-Azhar, hal tersebut merupakan satu hal krusial yang harus dilakukan pembenahan secara serius.

Abduh berkeyakinan bahwa jika universitas semacam al-Azhar itu diperbaiki, maka kondisi kaum Muslim akan membaik. Menurutnya, apabila alAzhar ingin diperbaiki, pembenahan administrasi dan pendidikan di dalamnya pun harus dibenahi, kurikulumnya diperluas, mencakup sebagian ilmu-ilmu modern, sehingga al-Azhar dapat berdiri sejajar dengan universitas-universitas lain di Eropa, serta menjadi mercusuar dan pelita bagi kaum muslimin pada zaman modern.

Hanya saja, pada waktu itu Abduh gagal meyakinkan para pemuda dan tokoh-tokoh lainnya untuk melakukan perbaikan terhadap al-Azhar. Lalu dia berusaha memperoleh dukungan al-Khudaywi untuk merestui rencananya, namun dia gagal juga. Hingga ketika Abbas Hilmi naik ke pentas kekuasaan, dia mengeluarkan kebijakan untuk membuat suatu panitia yang mengatur al-Azhar. Dalam kepanitiaan itu, Abduh mewakili pemerintah dan menjadi pemrakarsanya. Panitia itu berhasil menaikkan gaji para guru-guru yang miskin, memperhatikan tempat tinggal dan kesehatan orang-orang yang tinggal disekitarnya, serta memperbaiki kondisi perpustakaan yang sangat menyedihkan. Dan yang paling penting adalah menambahkan mata pelajaran di sana, yaitu berhitung, aljabar, sejarah Islam, bahasa dan sastra, dan prinsip-prinsip geometri dan geografi.

Selain itu, Abduh juga menghidupkan metode munazarah (discussion) dalam memahami pengetahuan yang sebelumnya banyak mengarah kepada taqlid semata terhadap pendapat ulama-ulama tertentu yang dianggap mempunyai berpengaruh. Hal tersebut diubahnya dengan jalan pengembangan kebebasan intelektual di kalangan mahasiswa al-Azhar. Demikian juga halnya dengan sikap ilmiah, terutama dalam memahami sumber-sumber ilmu agama yang selama ini memiliki landasan yang tidak dapat diganggu gugat oleh pemikiran dan kemajuan zaman. ${ }^{26}$

\footnotetext{
${ }^{25}$ Ibid, h. 308.

${ }^{26}$ Ibid, h. 312.
} 
Dengan perbaikan-perbaikan serta pembaharuan yang dibawa oleh Muhammad Abduh ke dalam tubuh al-Azhar, beliau berharap agar universitas ini kelak akan menjadi pusat pembaharuan yang diinginkan dalam dunia Islam. Akan tetapi usahanya ini kandas karena mendapat tantangan dari kalangan ulama yang kuat berpegang pada tradisi lama serta teguh dalam mempertahankannya. Namun demikian, di al-Azhar tersebut Abduh meninggalkan kelompok orangorang yang berpikir cerah, sekalipun hanya sedikit yang percaya pada prinsipprinsip yang diletakkan oleh Abduh dan menerima pandangan-pandangannya, dan sekalipun juga mereka tidak mempunyai keberanian dan kegairahan seperti Muhammad Abduh, ${ }^{27}$ baginya itu sudah cukup.

\section{SIMPULAN}

Ketertinggalan bangsa Muslim dibandingkan peradaban-peradaban bangsa Eropa, sedikit banyak telah menggugah kesadaran bangsa-bangsa Muslim untuk senantiasa melakukan pembaharuan-pembaharuan. Muhammad Abduh, sebagai salah satu tokoh pembaharu di Mesir telah sedikit banyak memberikan analisa mendalam mengenai penyebab kemunduran bangsa-bangsa Muslim. Dalam pandangannya problematika kejumudan dan taqlid buta merupakan faktor pokok penyebab ketertinggalan umat Muslim. Setidaknya ada beberapa pokok pemikiran Muhammad Abduh yang menjadi solusi tawaran atas problem krusial ketertinggalan bangsa-bangsa muslim tersebut. Pertama, perlunya Pembebasan pemikiran-pemikiran umat Muslim dari belenggu taqlid sehingga akal tidak tunduk pada otoritas manapun. Kedua, Purifikasi, yakni sebuah gerakan untuk melakukan pemurnian ajaran-ajaran Islam. Ketiga, Pembaharuan dalam lingkup pendidikan Islam dengan mencoba memasukkan ilmu-ilmu modern dan tawaran metodologi pembelajaran yang tidak kaku dan statis.

Setidaknya ada satu rekomendasi penting yang dapat penulis sampaikan sebagai penutup dalam pembahasan ini. Gagasan pembaharuan dalam Islam, seyogyanya saat ini harus mampu mengakomodasi berbagai persoalan dalam tubuh umat Islam. Hal itu dikarenakan, sebagaimana disadari bersama bahwa Islam saat ini semakin dicitrakan oleh beberapa media barat sebagai sebuah ajaran yang begitu sarat dengan kekerasan, fanatisme buta, radikalisme, kebobrokan moral dan lain sebagainya. Meskipun pada hakekatnya tuduhantuduhan tersebut sama sekali tidak benar dan tidak dibenarkan dalam ajaran Islam. Hanya saja, barangkali akibat kendornya upaya-upaya pembaharuan dalam Islam saat ini yang akibatnya kemudian membuat umat muslim nampak belum mampu untuk menangkal secara tegas tuduhan-tuduhan negatif tersebut. Sehingga dengan demikian, penulis menilai bahwa saat ini dibutuhkan sebuah kajian yang mendalam tentang bagaimana menyusun strategi yang kuat agar pembaharuan-pembaharuan dalam Islam mampu mengakomodasi persoalan

\footnotetext{
${ }^{27}$ Mukti Ali, Alam Pikiran Islam Modern di Timur Tengah, Jakarta: Djambatan, 1995, h.489.
} 
tersebut, dan menciptakan suasana dalam ajaran Islam yang benar-benar Rahmatan lil 'alamin.

\section{DAFTAR PUSTAKA}

Ahmad Amir, Pembaruan Teologi; Perspektif Modernisme Muhammad Abduh dan Neo Modernisme Fazlur Rahman, Yogyakarta: Teras, 2009.

Ahmad N. Amir, Abdi O. Shuriye, Ahmad F. Ismail, Muhammad Abduh's Contributions To Modernity, (volume1.no1. April 2012, asian Journal Of Natural \& Applied Sciences). www.ajsc. Leena-luna.co.jp.

---, The Foundation Of Science And Technology In View Of Muhammad Abduh, (Volume 1 No 2 Juni 2012, Asian Journal Of Natural \& Applied Sciences) www.ajsc. Leena-luna.co.jp.

Ali Rahnema (ed), Para Perintis Zaman Baru Islam, terj. Ilyas Hasan, Bandung: Mizan anggota IKAPI, 1996.

Erva Yuly Rakhmawanti, Muhammad Abduh dan Gagasan Pembaharuan Islam, (Makalah tidak diterbitkan).

H.A.R. Gibb, Aliran-aliran Modern dalam Islam, terj. Machnun Husein, Jakarta: PT Raja Grafindo Persada, 1993.

Harun Nasution, Pembaharuan dalam Islam; Sejarah Pemikiran dan Gerakan, Jakarta: Bulan Bintang, 1996.

, The Place Of Reason In Abduh's Theology (Its Impact on his Theological Sistem and Views), Dissertation, Montreal Kanada: McGill University Press, 1968.

Husayn ahmad amir, Seratus Tokoh dalam Sejarah Islam, terj. Bahruddin Fanani , Bandung: PT Remaja Rosdakarya, 1995.

John J. Donohue dan John L. Esposito (ed), Islam dan Pembaharuan; Ensiklopedi masalah-masalah, terj. Machnun Husein, Jakarta: Rajawali, 1984.

John L. Esposito, Ancaman Islam; Mitos atau Realitas?, Bandung: Mizan, 1996. 
Lexy J. Moleong, Metodologi Penelitian Kualitatif, Bandung: Remaja Rosdakarya, 2007.

M. Quraish Shihab, Studi Kritis Tafsir Al-Manar; Karya Muhammad Abduh dan M. Rasyid Ridha, Bandung: Pustaka Hidayah, 1994.

Majid Fakhry, Sejarah Filsafat Islam, terj. Mulyadhi Kartanegara, Jakarta: Pustaka Jaya, 1987.

M. Ihsan Dacholfany, Reformasi Pendidikan Islam Dalam Menghadapi Era Globalisasi: Sebuah Tantangan dan Harapan, AKADEMIKA, STAIN Metro, Vol. 20, No. 01 Januari - Juni 2015.

Muhammad Abduh, Risalah Tauhid, terj. Firdaus, Jakarta: Bulan Bintang, 1996.

Mukti Ali, Alam Pikiran Islam Modern di Timur Tengah, Jakarta: Djambatan,

Mukti Sahal dan Ahmad Amir Azizi, Teologi Islam Modern, Surabaya: Gitamedia Press, 1992.

Rob Fisher, "Pendekatan Filosofis", dalam Peter Connoly (ed), Aneka Pendekatan Studi Agama, Terj. Imam Khoiri ,Yogyakarta: LKIS, 2002

Sutrisno Hadi, Metodologi Research, Yogyakarta: Andi Offset, 1990.

Suwito dan Fauzan (ed), Sejarah Pemikiran Para Tokoh Pendidikan, Bandung: Angkasa, 2003. 